\title{
Pengaruh Perbedaan Sistem Perkawinan terhadap Lama Bunting dan Litter size Kelinci New Zealand White
}

\author{
The Effect of Mating System to the Duration of Pregnancy and Litter size of New Zealand \\ White Rabbit
}

\author{
P. Utami, D. Samsudewa, dan C. M. S. Lestari \\ Fakultas Peternakan dan Pertanian Universitas Diponegoro \\ Corresponding e-mail : Putriutami324@gmail.com
}

\begin{abstract}
The aim of this research was to compare the duration of pregnancy and litter size New Zealand White (NZW) rabbits that mated with natural mating and artificial insemination. Research used 32 doe and 2 buck. The treatment were NZW rabbits mated naturally and artificial insemination. The parameters observered were the duration of pregnancy and litter size NZW rabbits. Analysis of the data was analyzed using independent sample t-test and mann-whitney u-test. Independent sample t-test were used to determine the effect of mating system on the duration of pregnancy and litter size NZW rabbits, and to determine the effect of rabbit's physiology in the duration of pregnancy and litter size NZW rabbits whose mated with naturaly. Mann-whitney u-test were used to determine the effect of rabbit's physiology in the duration of pregnancy and litter size NZW rabbits whose mated that artificial insemination. The results showed that natural mating and artificial insemination has not significantly different $(\mathrm{P}>0.05)$ in the duration of pregnancy with the average of 31,70 days and litter size NZW rabbits with the average 4,32 litter. In mated naturally, coney and leveret has not significantly different $(\mathrm{P}>0,05)$ in the duration of pregnancy with the average 31,60 days and litter size with the average 4,89 litter, but in artificial insemination coney and leveret NZW rabbits has not significantly different $(\mathrm{P}>0,05)$ in the duration of pregnancy with the average 31,88 days and has significantly different $(\mathrm{P}<0.05)$ to the litter size NZW rabbits with the average of 2,50 to 5,00 litter.
\end{abstract}

Keywords: NZW Rabbit, The Duration of Pregnancy, Litter size

\begin{abstract}
ABSTRAK
Penelitian ini bertujuan untuk membandingkan lama bunting dan litter size kelinci NZW baik yang dikawinkan secara alami maupun inseminasi buatan. Penelitian ini menggunakan 32 kelinci betina dan 2 kelinci jantan. Perlakuan yang digunakan dalam penelitian ini adalah sistem perkawinan secara alami dan inseminasi buatan. Parameter yang diamati adalah lama bunting dan litter size. Penelitian ini menggunakan analisis independent sample t-test dan mann whitney u-test. Analisis ndependent sample t-test digunakan untuk mengetahui pengaruh sistem perkawinan terhadap lama bunting dan litter size, serta untuk mengetahui pengaruh status fisiologis kelinci terhadap lama bunting dan litter size kelinci NZW yang dikawinkan secara alami. Analisis Mann whitney $\mathrm{u}$-test digunakan untuk mengetahui pengaruh status fisiologis kelinci terhadap lama bunting dan litter size kelinci NZW yang dikawinkan secara inseminasi buatan. Hasil menunnjukkan bahwa perbedaan sistem perkawinan tidak memberikan pengaruh secara nyata $(\mathrm{P}>0,05)$ terhadap lama bunting dengan rata-rata 31,70 hari dan litter size kelinci NZW dengan rata-rata 4,32 ekor. Pada perkawinan secara alami, ststus fisiologis kelinci dara dan induk tidak memberikan pengaruh nyata $(\mathrm{p}>0,05)$ terhadap lama bunting dengan rata-rata 31,60 hari dan litter size dengan rata-rata 4,89 ekor. Pada perkawinan secara inseminasi buatan, status fisiologis kelinci dara dan induk tidak memberikan pengaruh nyata $(\mathrm{P}>0,05)$ terhadap lama bunting dengan rata-rata 31,88 hari, tapi memberikan pengaruh nyata $(\mathrm{P}<0,05)$ terhadap litter size dengan rata-rata 2,50-5,00 ekor.
\end{abstract}

Keywords: Kelinci NZW, Lama Bunting, Litter size

\section{PENDAHULUAN}

Kelinci merupakan salah satu ternak penghasil daging yang patut dipertimbangkan sebagai upaya dalam memenuhi kebutuhan protein hewani bagi masyarakat. Selain sebagai penghasil daging, kelinci juga dikenal sebagai hewan peliharaan dan hewan 
percobaan. Permintaan masyarakat akan kelinci saat ini masih tinggi dan diperkirakan akan terus meningkat, sehingga populasinya perlu diperhatikan. Salah satu cara untuk meningkatkan populasi kelinci yaitu dengan meningkatkan litter size.

Litter size dapat ditingkatkan melalui manajemen perkawinan yang baik dan benar, diantaranya meliputi pemilihan pejantan dan sistem perkawinan yang digunakan. Manajemen pemilihan pejantan mempengaruhi litter size, karena pejantan dengan kualitas semen yang rendah akan menghasilkan jumlah anak sedikit.

Sistem perkawinan kelinci dibedakan menjadi dua macam, yaitu sistem perkawinan alami dan buatan. Sistem perkawinan yang sering digunakan masyarakat yaitu secara alami, karena sistem ini mudah diterapkan dan memberikan angka persentase kebuntingan yang lebih tinggi dibandingkan sistem perkawinan buatan. Sistem perkawinan buatan yang memberikan hasil rendah diduga karena metode yang digunakan masyarakat kurang baik dan benar. Sistem perkawinan dengan manajemen yang benar akan memberikan hasil yang tinggi, sehingga sistem perkawinan buatan dapat memberikan hasil yang setidaknya sama atau lebih baik hasilnya dari perkawinan alami. Perkawinan dengan inseminasi buatan merupakan salah satu cara untuk memperbaiki mutu genetik, karena cara tersebut sangat efektif untuk meningkatkan kualitas maupun kuantitas ternak (Mukhtar, 2006), sehingga dengan laju reproduksi yang tinggi mampu memberikan keuntungan yang lebih banyak.

Penelitian ini bertujuan untuk membandingkan antara sistem perkawinan alami dan buatan terhadap lama bunting dan litter size kelinci NZW. Manfaat penelitian ini adalah untuk menambah wawasan peneliti dan untuk memberikan gambaran kepada peternak tentang sistem perkawinan yang lebih efektif dalam meningkatkan produktivitas. Diduga sistem perkawinan secara inseminasi buatan pada kelinci NZW menunjukkan hasil yang sama dengan sistem perkawinan secara alami.

\section{MATERI DAN METODE}

Penelitian ini dilaksanakan pada tanggal 7 Maret - 19 April 2016, bertempat di Balai Pembibitan dan Budidaya Ternak Non Ruminansia (BPBTNR) Provinsi Jawa Tengah di Surakarta.

\section{Materi}

Materi yang digunakan adalah 32 ekor kelinci NZW betina umur 6 bulan -2 tahun, bobot badan 1,6 - 3,0 kg. Selain itu digunakan pula 2 ekor kelinci NZW jantan umur 6 bulan -2 tahun, bobot badan 1,6 $3,0 \mathrm{~kg}$, sudah pernah mengawini, memiliki libido tinggi, dan memiliki catatan reproduksi baik.

Kelinci penelitian dipelihara pada kandang individu berukuran $80 \mathrm{~cm}$ x $80 \mathrm{~cm}$ x $70 \mathrm{~cm}$. Pakan kelinci berupa bekatul diberikan pukul 07.00 WIB, jerami kacang tanah diberikan pukul 12.00 WIB, dan pelet diberikan pukul 15.00 WIB. Air minum diberikan secara ad libitum.

Alat yang digunakan antara lain vagina buatan, tabung penampung semen, mikroskop, pipet tetes, kertas label, objek glass, cover glass, haemocytometer, bunsen, $\mathrm{pH}$ indikator, beker glass, spuit, dan kateter. Bahan-bahan pendukung antara lain adalah eosin $2 \%$, eosin $0,2 \%$, aquabidest, $\mathrm{NaCl}$ $0,9 \%$, dan HCG.

\section{Metode}

Rancangan penelitian ini menggunakan rancangan acak kelompok (RAK) dengan dua perlakuan dan dua kelompok. Perlakuan pertama (T0) untuk kelinci NZW yang dikawinkan secara alami, dan perlakuan kedua (T1) untuk kelinci NZW yang dikawinkan secara inseminasi buatan. Pengelompokan ini berdasarkan indikator status fisiologis ternak, kelompok pertama untuk kelinci dara dan kelompok kedua untuk kelinci induk.

Setiap perlakuan terdiri dari 16 ekor kelinci NZW (8 ekor kelinci dara dan 8 ekor kelinci induk). Pejantan yang digunakan berjumlah 2 yang merupakan pejantan terbaik dari 6 pejantan dan sudah dievaluasi 
semennya baik secara makroskopis maupun mikroskopis.

Sebelum perkawinan, dilakukan induksi ovulasi pada semua kelinci penelitian. Waktu yang tepat untuk induksi adalah 5-6 jam sebelum dilakukan kawin alam dan inseminasi buatan. Hormon yang digunakan adalah Human Chorionic Gonadotropin (HCG) secara intravena dengan dosis $30 \mathrm{IU} / \mathrm{ekor}$.

Pada perkawinan secara alami, induk kelinci yang estrus dimasukkan ke dalam kandang kelinci jantan dan dibiarkan untuk dikawini pejantan. Ciri-ciri perkawinan terjadi adalah jika pejantan menjatuhkan tubuhnya dengan posisi penis masih melakukan penetrasi ke vagina (kopulasi). Setelah terjadi dua kali perkawinan, induk dikembalikan ke kandangnya.

Pada perkawinan secara inseminasi buatan dilakukan melalui 3 tahap yaitu penampungan semen kelinci, pengenceran semen, dan inseminasi buatan. Proses penampungan dilakukan di dalam kandang dengan menggunakan kelinci betina sebagai pemancing. Pada saat kelinci pejantan terangsang, pejantan akan menaiki betina, pada saat pejantan ereksi, vagina buatan disorongkan kearah penis pejantan hingga terjadi ejakulasi, sebelumnya vagina buatan yang sudah dipasangkan pada tabung penampung diisi air hangat dengan suhu $39^{\circ}$ $-41^{\circ} \mathrm{C}$ dan diolesi pelicin serta ditutup kain pada bagian tabung penampung. Penampungan semen dilakukan pada ejakulasi pertama.

Pengenceran dilakukan dengan perbandingan 1:4 untuk semen : pengencer. Bahan pengencer yang digunakan adalah $\mathrm{NaCl}$ fisiologis $0,90 \%$, karena larutan ini memiliki tekanan osmotik yang ekuivalen dengan darah. Dosis yang digunakan untuk inseminasi buatan pada kelinci NZW adalah 0,5 cc/ekor dengan konsentrasi sperma sebesar $75 \times 10^{7}$ sel spermatozoa $/ \mathrm{ml}$.

Inseminasi buatan dilakukan 5 jam setelah penyuntikan hormon HCG. Semen cair hasil pengenceran diisap dengan kateter khusus yang dirancang untuk ternak kelinci sebanyak 0,5 cc, kemudian kateter dimasukkan ke dalam vagina dengan ujung yang membengkok diarahkan ke punggung induk kelinci, setelah bagian yang membengkok masuk kateter diputar $180^{\circ}$ dan terus didorong secara hati-hati sampai menyentuh serviks uteri. Selanjutnya semen cair disemprotkan perlahan-lahan dan kateter ditarik keluar.

Parameter yang diamati yaitu lama bunting dan litter size. Lama kebuntingan dinyatakan dalam hari dan dihitung mulai dari hari kelinci dikawinkan sampai pada hari kelinci melahirkan. Litter size dinyatakan dalam ekor dan diperoleh dengan menghitung total keseluruhan anak yang dilahirkan.

Analisis data yang digunakan dalam penelitian ini ada dua yaitu independent sample t-test dan uji mann-whitney. Analisis independent sample t-test digunakan untuk mengetahui pengaruh system perkawinan terhadap lama bunting dan litter size kelinci NZW, dan untuk mengetahui pengaruh status fisiologis kelinci terhadap lama bunting dan litter size kelinci NZW yang dikawinkan secara alami. Uji mann-whitney u-test digunakan pengaruh status fisiologis kelinci terhadap lama bunting dan litter size kelinci NZW yang dikawinkan secara inseminasi buatan. Uji independent t-test, dan uji mannwhitney u-test dilakukan dengan menggunakan aplikasi SPSS 16.

\section{HASIL DAN PEMBAHASAN}

\section{Lama Bunting}

Rata-rata lama bunting kelinci NZW yang dikawinkan secara kawin alam dan inseminasi buatan dapat dilihat pada Tabel 1.

Tabel 1. Rata-Rata Lama Bunting Kelinci NZW

\begin{tabular}{|c|c|c|c|}
\hline \multirow[t]{2}{*}{ Perlakuan } & \multicolumn{2}{|c|}{ Lama Bunting } & \multirow{2}{*}{$\begin{array}{l}\text { Rata- } \\
\text { Rata }\end{array}$} \\
\hline & Dara & Induk & \\
\hline & \multicolumn{3}{|c|}{---------- hari ---------- } \\
\hline T0 & 31,71 & 31,75 & 31,60 \\
\hline $\mathrm{T} 1$ & 31,50 & 32,00 & 31,88 \\
\hline
\end{tabular}


Hasil penelitian menunjukkan bahwa perbedaan sistem perkawinan baik secara alami maupun inseminasi buatan tidak memberikan pengaruh nyata $(\mathrm{P}>0,05)$ terhadap lama bunting kelinci NZW. Lama bunting kelinci NZW yang dikawinkan secara alami dan inseminasi buatan masih dalam kisaran normal (Tabel 1). Hal ini sesuai dengan pendapat Cheeke et al. (1987) yang menyatakan bahwa lama bunting pada ternak kelinci berkisar antara 30-33 hari.

Pada sistem perkawinan secara alami maupun inseminasi buatan menunjukkan hasil bahwa status fisiologi baik kelinci dara dan induk tidak memberikan pengaruh nyata $(\mathrm{P}>0,05)$ terhadap lama bunting kelinci NZW. Rata-rata lama bunting yang hampir sama diduga karena bangsa dan umur kelinci yang digunakan tidak berbeda yaitu menggunakan kelinci NZW dan memiliki umur 6 bulan - 2 tahun, sehingga pertumbuhan fetus membutuhkan waktu yang relatif sama. Waktu pertumbuhan fetus yang sama akan mengakibatkan waktu kebuntingan yang sama pula. Partodihardjo (1980) berpendapat bahwa lama bunting dipengaruhi oleh bangsa, umur, sifat khusus pewarisan dan jenis kelamin anak yang dikandung. Hammond (1925) menyatakan bahwa lama bunting pada kelinci paling dipengaruhi oleh pertumbuhan fetus yang dikandung. Hasil penelitian juga menunjukkan bahwa litter size yang dihasilkan dari kelinci dara lebih tinggi dibanding kelinci induk pada perkawinan alami dan lebih rendah dibanding kelinci induk pada perkawinan secara inseminasi buatan (Tabel 2). Hasil penelitian ini menunjukkan bahwa litter size yang berbeda tidak mempengaruhi lama bunting kelinci. Hal ini tidak sesuai dengan pendapat Cheek et al. (1987) bahwa dalam kasus kebuntingan yang panjang disebabkan oleh jumlah anak yang sedikit dengan ukuran badan besar dan juga pendapat Toelihere (1981) bahwa lama kebuntingan juga dipengaruhi oleh jumlah fetus dalam uterus, semakin banyak jumlah fetus maka lama kebuntingan semakin pendek.

\section{Litter size}

Rata-rata litter size kelinci NZW yang dikawinkan secara alami dan inseminasi buatan dapat dilihat pada Tabel 2 .

Tabel 2. Rata-Rata Litter size Kelinci NZW

\begin{tabular}{lccc}
\hline \multirow{2}{*}{ Perlakuan } & \multicolumn{2}{c}{ Litter size } & Rata- \\
\cline { 2 - 3 } & Dara & Induk & Rata \\
\hline & ---------- & ekor & ---------- \\
T0 & 5,28 & 4,50 & 4,89 \\
T1 & 2,50 & 5,00 & 3,75 \\
\hline
\end{tabular}

Hasil penelitian menunjukkan bahwa sistem perkawinan secara alami maupun inseminasi buatan tidak memberikan pengaruh nyata $(\mathrm{P}>0,05)$ terhadap litter size kelinci NZW. Rata-rata litter size hasil penelitian (Tabel 2) lebih rendah dari pendapat Lheukwumere (2008) yang menyatakan bahwa litter size kelinci NZW berkisar antara 5,00-6,35 ekor.

Pada sistem perkawinan secara alami menunjukkan hasil bahwa status fisiologis kelinci dara dan induk tidak memberikan pengaruh nyata $(\mathrm{P}>0,05)$ terhadap litter size kelinci NZW. Hal ini diduga karena faktor bangsa dan umur kelinci yang digunakan sama yaitu bangsa kelinci NZW dengan umur 6 bulan -2 tahun. Purnama (2000) menyatakan bahwa litter size dipengaruhi oleh bangsa, umur, lingkungan induk dan pakan yang diberikan.

Pada sistem perkawinan secara inseminasi buatan menunjukkan hasil bahwa status fisiologis kelinci dara dan induk memberikan pengaruh nyata $(\mathrm{P}<0,05)$ terhadap litter size kelinci NZW. Hasil litter size yang lebih tinggi pada kelinci induk (Tabel 2) diduga karena faktor paritas, kelinci yang sudah pernah melahirkan akan menghasilkan litter size yang lebih tinggi dibanding kelinci yang belum pernah melahirkan. Hal ini dikarenakan sel telur yang diovulasikan pada kelinci induk lebih banyak dibanding kelinci dara. Kelinci induk sudah terbiasa dengan proses ovulasi sehingga mempermudah proses ovulasi berikutnya, namun pada kelinci dara belum terbiasa dengan proses ovulasi sehingga sel telur yang dihasilkan pada perkawinan 
pertama menjadi lebih sedikit dibanding kelinci induk. Lebas et al. (1997) menyatakan bahwa litter size akan meningkat pada kelahiran kedua sebesar 10\%-20\%, namun akan menurun pada kelahiran ketiga dan tetap pada kelahiran keempat dan mengalami penurunan kembali pada kelahiran kelima dan seterusnya.

\section{KESIMPULAN}

Sistem perkawinan alami maupun inseminasi buatan tidak memberikan pengaruh nyata terhadap hasil lama bunting kelinci NZW dengan rata-rata 31,70 dan litter size kelinci NZW dengan rata-rata 4,32 ekor. Pada sistem perkawinan secara alami, status fisiologis kelinci dara dan induk tidak memberikan pengaruh nyata terhadap lama bunting kelinci NZW dengan rata-rata 31,60 hari dan litter size kelinci NZW dengan ratarata 4,89 ekor, sedangkan pada sistem perkawinan secara inseminasi buatan status fisiologis kelinci dara dan induk tidak memberikan pengaruh nyata terhadap lama bunting kelinci NZW dengan rata-rata 31,88 hari namun memberikan pengaruh nyata terhadap litter size kelinci NZW dengan kisaran 2,50-5,00 ekor.

\section{UCAPAN TERIMA KASIH}

Penulis mengucapkan terima kasih kepada pihak Balai Pembibitan dan Budidaya Ternak Non Ruminansia serta Balai Pelayanan Kesehatan Hewan Provinsi Jawa Tengah di Kota Surakarta yang telah mengijinkan penulis menggunakan fasilitas untuk penelitian dan telah membantu penulis dalam penelitian.

\section{DAFTAR PUSTAKA}

Cheeke, P.R., N. M. Patton, S. D. Lukefar, dan J. I. Mcnitt. 1987. Rabbit Production, Edisi 8. The Interstate Printers \& Publisher, United State America.

Eusebio, J. A. 1978. Pig Production in the Tropics, Cetakan 1. Longman Group Ltd, Hongkong.
Hafez, E.S.E. 1970. Rabbit, In: E.S.E. Hafez ed. Reproduction and Breeding Tecnique for Laboratory Animals. Lea $\&$ Febiger, Philadelphia.

Hammond, J. 1925. Reproduction in the Rabbit, pp 40 and 70. Oliver and Boyd, Edinburgh.

Lebas, F., P. Coudert, H. De Rochambeau, and R. G. Thebault. 1997. The Rabbit, Husbandry, Health and Production, New Revised Version. Food and Agriculture Organization of The United Nation, Rome.

Lestari, S. 2013. Profil kualitas semen segar sapi pejantan limousin dengan umur yang berbeda di Balai Inseminasi Buatan Lembang Jawa Barat. Jurnal Ilmiah Peternakan 1 (3): 1165 - 1172.

Lheukwumere, F. C. 2008. Effect of mixed feeding on litter performance traits of rabbit does. Pakistan Journal of Nutrition 7 (4): 594-596.

Minarti, Sri. 2010. Potensi litter size kelinci dengan penyuntikan hormon HCG (Human Chorionic Gonadotrophin) pada level pakan tradisional. JIIPB 20 (1): 92-97.

Mukhtar, A. 2006. Ilmu Produksi Ternak Perah, Cetakan 1. Lembaga Pengembangan Pendidikan dan Universitas Sebelas Maret Press, Surakarta.

Partodihardjo, S. 1980. Ilmu Reproduksi Hewan. Penerbit Mutiara, Jakarta.

Purnama, R. D. 2000. Pola Reproduksi pada Kelinci. Dalam: Temu Teknis Fungsional non Peneliti: 99-104.

Rhodes, M. T., D. L. Davis, E. S. Stevenson. 1991. Flushing and altrenogest affect litter trait in gilf. J. Anim. Sci 69: 34-40.

Saptono, H. S. 2012. Tingkat Keberhasilan Inseminasi Buatan pada Sapi Perah Rakyat di Kecamatan Mojosongo Kabupaten Boyolali. Universitas Sebelas Maret, Surakarta. (Skripsi)

Toelihere, M. R. 1981. Fisiologi Reproduksi pada Ternak. Angkasa, Bandung. 